\title{
Challenges and Solutions for Teachers' Use of Interactive Whiteboards in High Schools
}

\author{
Mokibelo Michael Mokoena ${ }^{1}$, Sibongile Simelane-Mnisi, ${ }^{2, *}$, Andile Mji ${ }^{1}$ \\ ${ }^{1}$ Faculty of Humanities, Tshwane University of Technology, Pretoria, South Africa \\ ${ }^{2}$ Higher Education Development \& Support, Department of Curriculum Development \& Support: ELearning, \\ Tshwane University of Technology, Pretoria, South Africa
}

Received August 27, 2021; Revised November 26, 2021; Accepted December 22, 2021

\begin{abstract}
Cite This Paper in the following Citation Styles
(a): [1] Mokibelo Michael Mokoena, Sibongile Simelane-Mnisi, Andile Mji , "Challenges and Solutions for Teachers' Use of Interactive Whiteboards in High Schools," Universal Journal of Educational Research, Vol. 10, No. 1, pp. 36 - 47, 2022. DOI: 10.13189/ujer.2022.100104.
\end{abstract}

(b): Mokibelo Michael Mokoena, Sibongile Simelane-Mnisi, Andile Mji (2022). Challenges and Solutions for Teachers' Use of Interactive Whiteboards in High Schools. Universal Journal of Educational Research, 10(1), 36 - 47. DOI: 10.13189/ujer.2022.100104.

Copyright $\bigcirc 2022$ by authors, all rights reserved. Authors agree that this article remains permanently open access under the terms of the Creative Commons Attribution License 4.0 International License

\begin{abstract}
The paper reports on the challenges teachers encountered in the use of interactive whiteboards in high schools to make improvement. The Gauteng Department of Basic Education's robust paperless initiative of introducing tablets, interactive whiteboards (IWBs), and smart classrooms in all public schools in Gauteng Province, motivated this study. In addition, little is known about teachers' academic self-efficacy when using an IWB-based teaching method. It was found that teachers experienced challenges in utilizing the IWB in teaching and learning. Participants were 123 teachers from four high schools in Tshwane North District, Gauteng, South Africa. More than half $(57.8 \%)$ of the teachers were females. Most of the teachers $(92.7 \%)$ received formal training on the use of IWBs. The mixed method was applied to better understand the phenomenon. Observation and individual semi-structured interviews were used to collect data for the qualitative aspect. On the other hand, Bandura's adapted problem-solving self-efficacy survey questionnaire was used to address the quantitative part. Quantitative data were analyzed using SPSS version 25 frequency distributions and percentages. On the other hand, qualitative data were analyzed with the aid of Atlas ti. The results show that $75.6 \%$ of the teachers indicated that they cannot solve problems at $90 \%$ when using IWBs in class. The challenges found in this study relate to technic, teaching material and lessons, lack of engagement, health, and lack of electricity. It was indicated that if teachers
\end{abstract}

could adopt positive problem orientation, they could be successful in solving the problem with the use of IWBs. It is necessary to investigate the efficacy of the solutions presented in this study when using IWBs.

Keywords Interactive Whiteboards, Problem Solving Self-efficacy, Challenges, Solutions, High School

\section{Introduction}

Several international and national schools have invested in interactive whiteboard technology to enhance teaching and learning, and promote engagement among the learners $[1,2]$. The Gauteng Department of Education in South Africa followed suit in assuring the use of technology in teaching and learning, and many schools were equipped with interactive whiteboards (IWBs). The IWBs, if used effectively in the subjects, have the potential to bring joy and excitement to teachers and learners. [3] argued that the IWBs were likely to facilitate a diverse range of multi-modality, and it improves the quality of learners' work, as it facilitates more dialogic or interactive teaching. In this case, it may be argued that the IWB has the potential to promote students' engagement, communication, and collaboration during the learning process. 
Several benefits of IWBs in teaching and learning in schools have been identified in the literature $[4,5,3,6]$. IWBs enables learning interaction between learners and teachers [4], wherein learners manipulate the IWB technology to participate [5]. [7] argued that IWBs allows learners to go to the front and interact with the interactive features to develop 21st-century skills, higher-order thinking and problem-solving. It was found that in the mathematics classroom where IWB was used, learners' interest, participation and motivation were increased, as better results were achieved [6]. IWBs can bring fun to the classroom due to its flexibility and versatility [8]. To support the identified benefits, [3] reported the usefulness, and ease of use of IWBs. However, research shows that as much as many teachers have IWBs in their classrooms, it was either underutilized, or not used at all [7].

The underutilization of the IWBs was brought about by several challenges teachers encountered in their teaching practices. In this case, the teacher-centered and lecture methods were observed, even when teachers were using the IWB instead of an interactive approach to teaching [6]. In South Africa, it was found that teachers were writing on the screen using their fingers, more or less the same as they would on a chalkboard [2]. These authors argued that teachers had substituted the chalkboard with the IWB, yet still applied the same teaching styles. In Turkey, [3] revealed the lack of compatible digital materials, technical problems, and teachers' pedagogical philosophies of learning with technology. Furthermore, in South Africa, [7] identified challenges relating to technical glitches that can waste a lot of teaching time, including lack of internet connection, and lack of electricity connection. These challenges need to be overcome by means of solutions in order to be used and aligned to individual schools.

Problem-solving self-efficacy was identified as one of the solutions that are required to be explored when utilizing technology in schools. Self-efficacy is defined as an individual's belief in his or her ability to systematize and perform the sequence of actions required to complete a task, or achieve a goal $[9,10]$. Models of self-efficacy suggest that high levels of computer self-efficacy might positively influence an individual's adoption of technology and uptake in a classroom [11]. Teachers with a high level of technology self-efficacy are more likely to adopt new technologies like IWBs in their teaching and learning practices [12]. Individuals with low self-efficacy, on the other hand, require greater inspiration from their environment [13]. Problem-solving is defined as the process one comes up with effective means of handling a problematic situation [14]. Problem-solving skills allow individuals to generate alternatives and evaluate the pros and cons of such alternatives [14].

Problem-solving style, in this sense, refers to cognitive and behavioral processes assisting a person to understand challenges and discover solutions. [14] argues that problems represent a discrepancy between an actual situation and its desired state. On the other hand, solutions represent the responses given to change the nature of a problem [14]. Hence, in this study, the teachers had to rate their confidence in solving a problem when using IWBs. It is argued that teachers have problem-solving abilities which could lead to the better use of IWBs. Problems are unavoidable, and therefore a source of stress and anxiety appears. Problem-solving efficacy is evident in the study conducted by [15], which aimed to reduce anxiety among College Algebra learners.

\section{Related Literature}

\subsection{Interactive Whiteboard Teaching and Learning Material}

[16] points out that the IWB enables teachers to interact with digital materials through its interactive features in a manner not possible through other education technologies. These authors indicated that materials in the IWB improve whole-class teaching due to its visual impact and interactivity features. Furthermore, IWB materials were reported to have increased active participation and engagement from learners [17]. IWBs were also reported to have generated excitement and a positive attitude to learning [18]. Literature shows that IWBs contain important Mathematical materials, which enable learners to gain access to a variety of unusual solution sets [19]. In addition, IWB materials provide a fun atmosphere, and long-lasting memory of words when used in an English vocabulary classroom [20]. However, in South Africa, it was found that IWBs do not have interactive material for local languages, and only textbooks were available [21]. The effective use of IWB material obliges teachers to understand interactive teaching methods [2]. It may be argued in this study that, when these materials are used with the aim to solve the problems encountered in class as a solution to achieve learning objectives, it may increase learners' academic performance and teachers' confidence to use the tool.

The purpose of this study was to identify and explain the challenges teachers encountered in the use of IWBs in high schools, and to provide improved solutions. To do this, observations, individual semi-structured interviews and Bandura's problem-solving self-efficacy were utilized. The observations were conducted to establish teachers' use of IWBs, and the subsequent challenges experienced in learning and teaching practices. The individual semi-structured interviews were also conducted to ascertain teachers' perceptions on the utilization of IWB. Bandura's problem-solving self-efficacy determined teachers' confidence in solving a problem when using IWBs in teaching practices.

\subsection{Benefits of Interactive Whiteboard}

To help teachers to understand the use of IWBs in a 
teaching and learning environment, it is vital to consider teacher development as a priority [21]. According to research, IWBs has the advantage of building a learner-centered approach [8]. The IWB enables the teacher to cover more topics or expand the scope of the class, as well as improve teaching strategies [22], which enhances students' attention to their teachings [23]. The usage of videos and photographs on the IWB proved to be beneficial to learners, as it appears to be the familiar characters that learners have grown up with [24]; [22,7]. Furthermore, the multimedia on IWBs further increases the visual appeal to learners [8]. The other beneficial aspect of IWBs is that it has a storage capability, as [7] and [8] note out, which allows for continued usage of saved lessons. It is imperative that the benefits identified in this study be taken into consideration when using IWBs in pedagogy.

\subsection{Interactive Whiteboard Challenges}

Challenges in the use of IWBs are categorized into pedagogical and technical problems [8]. One of the challenges that [7] are viewed to be impeding the efficient use of technology in a teaching and learning environment, is the lack of expertise in the IWB. Teachers' lack of experience, according to this author, causes them to use the IWB inefficiently or not at all. The other challenge is that, within a teaching and learning environment where the IWBs were deployed, the teacher's role was undermined or undervalued due to the focus and emphasis being on the technology, and not pedagogy [25]. The usage of IWBs may also be impeded by classroom organization, according to [20], as overcrowded classes are not conducive to the use of IWBs. [7] further stated that there was a lack of support and attention from the school principals in how teachers use IWBs within the classroom. The IWBs could be harmful to students' and teachers' health, as it can cause eye strain [20]. To overcome these challenges of IWBs in teaching and learning, teacher professional development on the pedagogical use of IWBs is vital [21]. The most widely held belief for a more effective adoption lies in the fact that teachers should be the stakeholders and custodians of IWB integration in teaching and learning.

\subsection{Theoretical Framework}

The theoretical framework grounding this study was Bandura's problem-solving self-efficacy. Self-efficacy is the individual's belief about his/her capabilities to organize and execute the courses of action required to manage prospective situations [10]. This author has shown that self-efficacy has an impact on an individual's psychological state, motivation, how people think, behave, and feel [10]. Self-efficacy can be strengthened through Bandura's [10] four mechanisms of performance, being outcome, social modelling or vicarious experiences, verbal or social persuasions, and physiological states. Establishing the relationship between perceived ability and performance in problem-solving could serve as high school program efforts. This study may also serve as a benchmark for teacher researchers in the basic education sector, who are interested in self-efficacy in general, and problem-solving efficacy in particular. [14] argues that the problem-solving style presents cognitive and behavioral activities for enabling a person to understand problems and find solutions. Research shows that people who have a positive problem orientation are inclined to view a problem as a challenge. That problems are present and should be solved [14]. These people solve the problem with success. Literature also revealed that high self-efficacy promotes better performance in problem-solving [15]. However, people having negative problem orientation see the problem as a threat to one's own existence. They believe that problems are very difficult to solve. They do not have confidence in themselves, and they easily become distressed when confronted with a problem [14].

\section{Materials and Methods}

The questions posed in this paper are: What were the teachers' challenges with the use of IWBs in schools? What are the solutions that teachers could use to advance the use of IWBs? To answer these questions, a mixed method was used that combines qualitative and quantitative approaches in a single study [26]. Ethical clearance was granted in 2017 by the study university and the Department of Basic Education to conduct the study. Observation and individual semi-structured interviews were used to collect data for the qualitative aspect. These instruments supported the establishment of the challenges teachers encountered with the use of IWBs. In addition, Bandura's problem-solving self-efficacy was used to address the quantitative part. The problem-solving self-efficacy instruments assisted the teachers to rate their confidence in solving subject-related problems when using IWBs. Qualitative data were analyzed through Atlas ti. Quantitative data were analyzed using SPSS version 25, using frequency distributions and percentages.

\subsection{Participants}

The population in this study was 1457 teachers. Purposeful and simple random sampling techniques were used to sample 123 teachers, who were randomly selected from 41 high schools. The aim of purposive sampling was to draw a specific sample from a population that will allow the researcher to examine a phenomenon most effectively [27]. In simple random sampling, each member of the population has an equal chance of being selected and is mostly used in quantitative research. Table 
1 shows the biographical data of the participants. The results show that more than half $(57.7 \%)$ of the teachers were female. In terms of age, $53.4 \%$ of the participants were aged 40 and above. It may be seen from the table that $92.7 \%$ of the teachers received formal training in the use of the IWB. Less than a quarter (22.8\%) of the teachers taught Life Orientation, 20.3\% Mathematics and English Additional Language, $10.6 \%$ Life Science and Geography, 9.8\% Business Studies, and 8.1\% Physics, History and Accounting.

Table 1. Participants’ Biographical Data

\begin{tabular}{|c|c|c|c|}
\hline & & No. & $\%$ \\
\hline \multirow[t]{2}{*}{ Gender } & Female & 71 & 57.7 \\
\hline & Male & 52 & 42.3 \\
\hline \multirow[t]{2}{*}{ Age in range } & $20-39$ & 61 & 46.6 \\
\hline & 40 and above & 62 & 53.4 \\
\hline \multirow[t]{2}{*}{$\begin{array}{c}\text { Interactive } \\
\text { whiteboard } \\
\text { training }\end{array}$} & Formal & 114 & 92.7 \\
\hline & No training & 9 & 7.3 \\
\hline \multirow[t]{16}{*}{ Subject Teaching } & Sepedi & 8 & 6.5 \\
\hline & Setswana & 8 & 6.5 \\
\hline & IsiZulu & 3 & 2.4 \\
\hline & Tsonga & 1 & 0.8 \\
\hline & $\begin{array}{c}\text { English } \\
\text { Additional } \\
\text { Language }\end{array}$ & 25 & 20.3 \\
\hline & Mathematics & 31 & 25.2 \\
\hline & Technology & 2 & 1.6 \\
\hline & $\begin{array}{c}\text { Computer } \\
\text { Application }\end{array}$ & 4 & 3.3 \\
\hline & Life Science & 15 & 12.2 \\
\hline & Physics & 10 & 8.1 \\
\hline & History & 11 & 8.8 \\
\hline & Geography & 13 & 10.6 \\
\hline & Business Studies & 12 & 12.2 \\
\hline & C Arts & 1 & 0.8 \\
\hline & Accounting & 10 & 8.1 \\
\hline & Life Orientation & 28 & 22.8 \\
\hline
\end{tabular}

\subsection{Instruments and Procedure}

The instruments used in this study were Banduras' problem-solving self-efficacy survey questionnaire, non-participatory observation, and individual semi-structured interviews. Problem-solving self-efficacy were analyzed with the aid of SPSS frequency distribution and percentages. Atlas.ti was used to analyze data from observations and interviews. Interviews were performed at schools during lunch breaks or at the end of the prescribed school timetable, whereas observations were conducted during normal school lesson periods according to the class timetable for high schools. In analyzing data in Atlas.ti, firstly, the researcher started by creating the hermeneutic unit called IWB Project. In this hermeneutic unit, two primary documents were uploaded. P1 represents data from observations, and P2 represents data from interviews. From these documents, the researcher coded 167 codes. The codes were then grouped into four conceptual networks relating to IWB training, teachers' use of IWBs in class, materials on IWB, and IWB challenges.

\subsubsection{Problem-Solving Self-Efficacy}

Before using the problem-solving self-efficacy in South Africa, a letter requesting permission to use the instrument was written to Professor Bandura, who granted permission. The survey questionnaire was divided into two Sections. Section A collected teachers' biographical data. Section B collected quantitative data on teachers' problem-solving efficacy (PSSE). Teachers rated their confidence in solving a problem when using IWB in the teaching practices. Teachers had to rate themselves from 10\% - 100\% confidence. The scale used the following ratings: Cannot do at all (0-40\%); moderately can do (50-80\%), and highly certain can do (90-100\%). The efficacy scale with the $0-100$ response format is a stronger predictor of performance than one with a 5-interval scale [28]. The reliability of the problem-solving self-efficacy was assessed by computing Cronbach's alpha [29]. When looking at the scores for the entire scale with 10 items for internal consistency, the Cronbach's alpha values were .94 . The alpha values of the subscale ranged between 0.93 and 0.94 . Table 2 shows the number of items on a scale, as well as alpha values.

Table 2. Number of Items and Alpha Values

\begin{tabular}{|c|c|}
\hline No. of items & Alpha \\
\hline PSSE10 & .93 \\
\hline PSSE20 & .93 \\
\hline PSSE30 & .93 \\
\hline PSSE40 & .93 \\
\hline PSSE50 & .93 \\
\hline PSSE60 & .93 \\
\hline PSSE70 & .93 \\
\hline PSSE80 & .93 \\
\hline PSSE90 & .94 \\
\hline PSSE100 & .94 \\
\hline TOTAL & .94 \\
\hline
\end{tabular}

\subsubsection{Observations}

Between August and September 2017, observations were recorded with five teachers in five high schools that had implemented IWBs. Three of the schools were in the township, while the other two were in rural areas. A non-participant observer was used by the researchers. This indicates that the researchers did not interfere with the 
usual operation of school programs. The researcher spent a maximum of 20 minutes in a 30-minute lesson without interfering with the lesson.

- How do teachers use the IWB during lessons?

- What are the challenges encountered by teachers during the lesson when using IWB?

\subsubsection{Individual Interviews}

During the individual semi-structured interviews of 18 teachers, researchers used the guiding questions as to what to ask. Data were recorded from the outsider's point of view [30]. The interviewees responded to the following research questions:

- Did you receive training on the use of an IWB? Yes/No elaborate on the training

- How do you use the IWB in class?

- Does the IWB contain materials that assist you in doing lesson preparations and assessments?

- What are the challenges you experience from the optimal use of IWB?

\section{Results}

\subsection{IWB Problem-Solving Self-efficacy}

Table 3. Teachers' Confidence in Solving Problems When Using IWB Self-Efficacy

\begin{tabular}{|c|c|c|c|}
\hline Item & $\begin{array}{c}\text { Cannot do } \\
\text { at all } \\
\mathbf{0 - 4 0} \%)\end{array}$ & $\begin{array}{c}\text { Moderately } \\
\text { can do } \\
\mathbf{( 5 0 - 8 0 \% )}\end{array}$ & $\begin{array}{c}\text { Highly certain } \\
\text { can do } \\
\mathbf{( 9 0 - 1 0 0 \% )}\end{array}$ \\
\hline PSSE10\% & $23(18.7)$ & $59(48.0)$ & $41(33.3)$ \\
\hline PSSE20\% & $24(19.5)$ & $65(52.8)$ & $34(27.6)$ \\
\hline PSSE30\% & $28(22.8)$ & $73(59.3)$ & $22(17.95)$ \\
\hline PSSE40\% & $31(25.2)$ & $80(65.0)$ & $12(9.8)$ \\
\hline PSSE50\% & $42(34.1)$ & $71(57.7)$ & $10(8.1)$ \\
\hline PSSE60\% & $60(48.8)$ & $55(44.7)$ & $8(6.5)$ \\
\hline PSSE70\% & $73(59.3)$ & $44(35.8)$ & $6(4.9)$ \\
\hline PSSE80\% & $89(72.4)$ & $27(22.0)$ & $7(5.7)$ \\
\hline PSSE90\% & $93(75.6)$ & $24(19.5)$ & $6(4.9)$ \\
\hline PSSE100\% & $83(67.5)$ & $31(25.2)$ & $9(7.3)$ \\
\hline
\end{tabular}

Table 3 shows the results of the teachers' rating of their confidence in solving problems when using IWBs. It may be seen from the results that teachers indicated they are able to moderately solve IWB problems when teaching (at $10 \%-50 \%)$. An overwhelming $60 \%-100 \%$ of the teachers revealed they are unable to solve IWB problems. Concerning their rate of level of confidence, the results show that one in three $(65.0 \%)$ teachers can moderately solve problems at $40 \%$ when using IWBs. This was followed by more than half $(59.3 \%)$ at $30 \%, 57.7 \%$ at $50 \%$, and $52.8 \%$ at $20 \%$. Lastly, less than half (48.0\%) of the teachers indicated that they can moderately solve problems at $10 \%$ with the IWB when teaching. Regarding teachers' level of confidence of not solving IWB problems. The results revealed that approximately three out of four teachers $(75.6 \%)$, at $90 \%$, indicated they are unable to solve problems when using the IWB in class. This was followed by one in three $(72.4 \%)$ at $80 \%$, and $67.5 \%$ at $100 \%$. More than half (59.3\%) at $70 \%$, and lastly, less than half $(48.8 \%)$ at $60 \%$ of the teachers indicated they are unable to solve problems when attempting to incorporate the IWB in teaching practice.

\subsection{Observations}

For this paper, two questions from the observation tool were used. In Question 1, the researchers gathered data on the teachers' use of IWBs during the lessons. The theme, teachers' use of IWBs in the class, was generated. In terms of Yes, I use IWB, Teacher Molotsi said: Yes, she uses IWB. Teacher Nkomo indicated: "Yes, he does use". Teacher Maphalala and Moloi indicated they are writing on the screen using their fingers. Concerning display loaded textbook, Teacher Nkomo loaded and displayed the textbook on the IWB. Teacher Radebe loaded and displayed the textbook by page number, and learners read from the screen. In terms of PowerPoint presentation, Teacher Mofokeng used the USB to load a presentation by means of the IWB USB port, the presentation was displayed on the IWB, and he taught via it. Concerning the teacher-centred approach, Teacher Moloi indicated that she used it and she instructed learners who were not participating in the lesson to follow her lead; the lesson was teacher-controlled.

Concerning the observation on being unable to use the IWB, Teacher Nkomo was not properly equipped to use the IWB; she only displayed the topic of the lesson. She struggled to connect the presentation. It was a challenge for her to use the IWB. She therefore reverted to the whiteboard, which was next to the IWB. In terms of teacher use of IWB in the class, the researchers observed that Teacher Mofokeng displayed a limitation in the use of IWB regarding learners reading from the screen. Teacher Moloi was observed displaying a loaded textbook on the IWB. She instructed learners to read from the screen. In terms of IWB not being effectively used, the researchers observed that Teacher Nkomo struggled to utilize the IWBs' built-in features. She kept referring learners to the textbook. About the use of USB, teachers used the USB facility to access the material on the IWB. The researchers observed Teacher Mofokeng using the USB to load a slide presentation. In terms of subjects, teachers taught different subjects when using the IWB. Teacher Maphalala taught Life Sciences, and Teacher Radebe Mathematics. In terms of lesson topics, the findings revealed that teachers taught a variety of topics. Teacher Radebe taught Mathematics on the topic of statistics. Teacher Mofokeng taught a Mathematics Literacy lesson on word sums. Teacher Nkomo taught Sepedi on Diema (Idioms), and Teacher Moloi taught Business Economics on macroeconomics. 
In Question 2, the researchers responded to the challenges encountered by teachers during the lesson when using IWBs. This question was merged with Question 5 from the semi-structured interviews. The theme of IWB challenges was created. Figure 1 shows the conceptual network relating to IWB challenges. It was found that the researchers observed Teacher Maphalala using the IWB, and it got stuck in the middle of the lesson. He then switched off the IWB, and subsequently restarted it. When teacher Mofokeng began the lesson, the researchers observed the IWB took time to load information. The researchers also observed the IWB freezing up. Teacher Maphalala decided to restart the IWB. The findings revealed that most of the teachers indicated slow access to the IWB, which led to the loss of teaching time. Teacher Daniel said: sometimes when he reopens the IWB, it takes longer, resulting in the loss of valuable teaching time. In addition, the researchers observed that Teacher Nkomo attempted to use the IWB. She struggled, whereafter she resorted to teaching using the textbook. When teacher Maphalala wanted to use audio from the lesson presented on the IWB, the IWB lacked audio enhancement. It was found that one of the teachers indicated that the IWB did not have a signal in other instances. Teacher Eugene indicated that the only challenge was when he came to class and found out that IWB was out of the system. He stated that he could not access it, as the system refused to start up. At times, there was no signal. The findings also revealed that one of the teachers has a problem linking learners' mobile devices to the IWB. Teacher Mhlongo mentioned that he was unable to link with learners' smartphones and tablets, as there was no internet connectivity.
It was also found that the researchers observed Teacher Mofokeng struggling to add information or draw statistical graphs, which were not in the slide presentation. The researchers also observed that the IWB takes time to load information during Teacher Mofokeng's lesson. It was also found within all the observed classes that the IWB lacked an internet connection. Hence, teachers were presenting lessons using PowerPoint presentations. They could not access teaching material online. Furthermore, the researchers observed the IWB screen shut down during the lesson presented by Teacher Maphalala. It was found that IWBs does not contain vernacular materials. One teacher stated that, for African languages, the IWB does not incorporate the relevant material. Here, Teacher Zwane responded that the IWB did not have vernacular material. It was therefore found that participation was not promoted in some classes. Teacher Zulu said she could not interact with the learners. It was found that one of the teachers revealed health hazards with the use of IWB. Teacher Smith said: Maybe he can talk about his life. The IWB light is affecting my eyes. Every day is affecting my eyes. It was also found that the major challenge with the use of IWB in school was the electricity failure - the so-called load shedding implemented in South Africa. Teacher Nkosi said, yes, if there was no electricity. Teacher Khoza indicated, more especially when there was no electricity due to load shedding. Teacher King mentioned that if the cables were stolen or no electricity, they experienced the problem. It was also found that, in some instances, the researchers observed some of the teachers' lessons ran smoothly with no problems, such as Teacher Moloi's and Teacher Mofokeng’s lessons. 


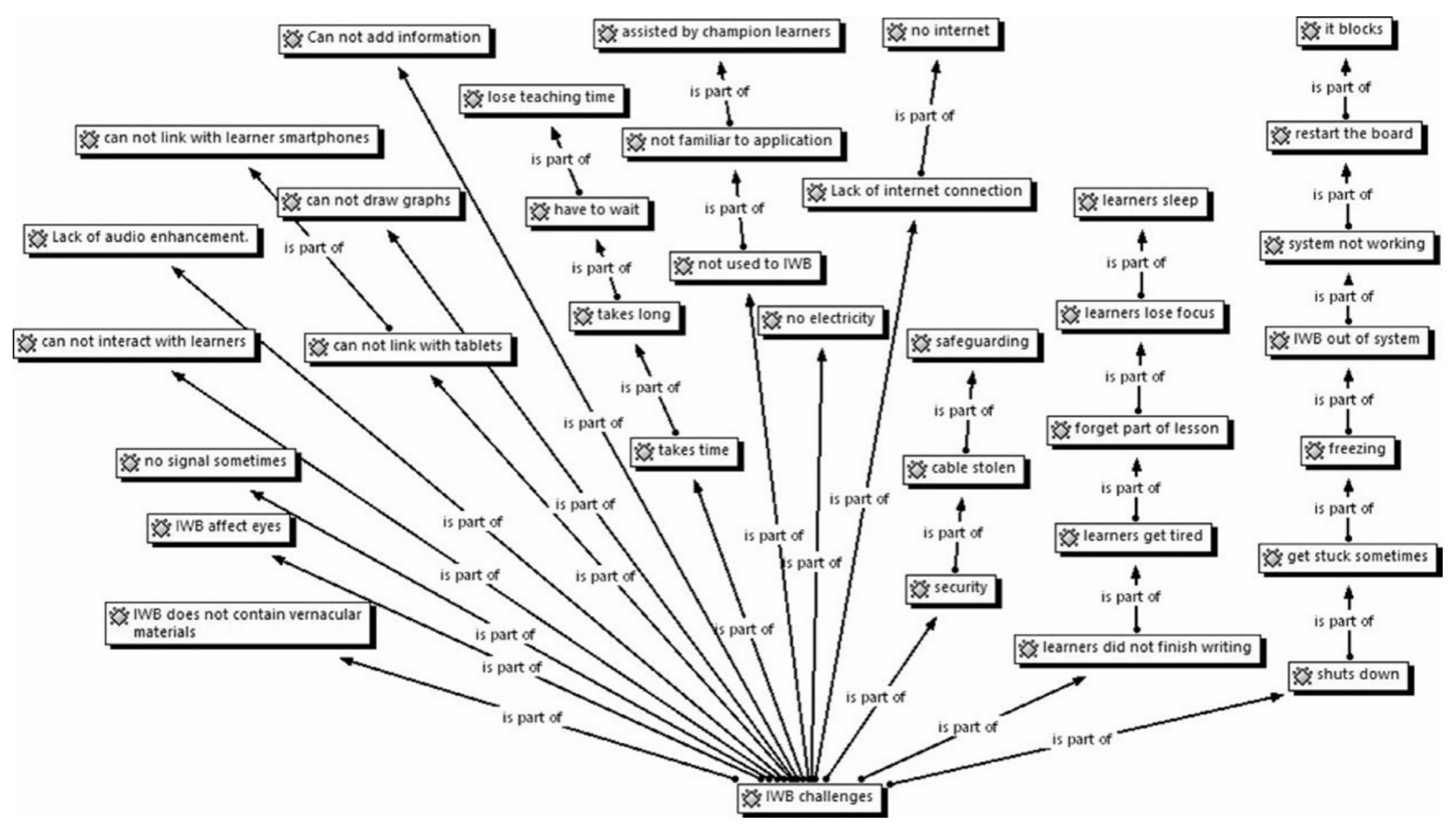

Figure 1. The network or conceptualization relating to IWB challenges 


\subsection{Individual Interviews}

Four questions from the individual semi-structured interviews were used. In Question 1, teachers were requested to respond to the question: Did you receive training on the use of IWB? Yes/No elaborate on the training. The theme of IWB training was generated.

It was found that few teachers revealed that they attended IWB training. Teacher Zwane, Teacher Mooka and Teacher Puleng said yes. They did receive training. It was clear that, even if teachers received IWB training, it was not sufficient in terms of its duration. Teacher Aphane revealed that you know ICT needs enough training. The type of training that was for five hours was not enough. Other teachers indicated their frustration with the type of training. Teacher Baloyi indicated that it frustrated him sometimes because he needed to do some of the things, but he could not because he thought he was not well trained to be able to use IWB effectively in the lessons. It was found that the time allocated for training varied and was greatly insufficient. Teacher Peters indicated they were trained for 2 hours. Teacher Khosi indicated, three months, in the afternoon. Teacher Sepeng said they did receive training normally after school, maybe twice a week. It was also found that other teachers indicated they were trained during weekdays. Teacher Padi indicated that the training was on Tuesday and Thursday. Teacher Dube said they used to have classes or meet every Wednesday to familiarize themselves with IWB.

In Question 2, teachers were asked to respond to the question: How do you use IWB in class. The theme, teacher use of IWB in class, was generated. It was found that the usage of IWBs varied according to teachers. Teacher Mhlongo said she used IWB almost. Teacher Phiri responded by saying, yes but not every day, because of the set marker, and Teacher Maake said, yes, he used IWB on daily basis. The teachers revealed that they used the IWB mostly for writing. This implies that teachers were used to the chalkboard, but the IWB had more features that allowed interactivity. Teacher Phetla indicated that he writes on it, but it is the only thing he does on the IWB. Teacher Pudi said he uses it to write notes and definitions of words. It was also found that teachers indicated that the IWB had loaded textbook material. Teacher Nxesi responded that it was easy for him, he was not sure about the other teachers, because IWB contained the material in textbooks, which were loaded for them. Teacher Zondi indicated that normally he prepares his lessons and save them in the IWB. Teacher Ngwenya said that unfortunately with the classes that she has, one does not have the IWB, and the other class has the IWB, but it does not have enough material related to the subject that she was teaching. Therefore, she currently plans her own lessons on the use of the IWB.

Teachers revealed that they use laptops to prepare presentations at home, then project them in class from the IWB. Teacher Johnson said that he could save his material from the laptop and prepare the lessons from home. Then he could use his laptop and project it on the IWB. Teacher Thomas indicated that, for Life Sciences, he uses the IWB to project the lessons, videos, and experiments. It was found that some of the teachers mentioned challenges they encountered hinder them from effectively using IWBs. It was found that some of the teachers battled to switch on the IWB in order to use it in class, yet others managed. Teacher Pete indicated when she switches on the IWB, the problem was difficult as the textbook was behind her. She therefore moves away from the book on the screen and starts writing on the whiteboard. She realized that she blocked access for learners to view the content on the IWB. Sometimes the IWB freezes, and it is difficult to proceed with the lesson. Teacher Zitha said that he does not know how to use the IWB, yet they are there in class. Teacher Bheki mentioned that he could always click on the IWB and open the lesson preparation. The findings revealed some of the teachers indicated they allowed learners to use their USB to connect to the IWB. Teacher Zuma mentioned that he allowed learners to use the IWB, since they play their USB full of music. He encouraged them to use the IWB as it makes the lesson more interesting on the learner side. Some of the teachers mentioned that they allowed learners to use the IWB in class. Teacher Sipho said, unfortunately, there was no practical in accounting; therefore, he gave learners the opportunity to explain something in the lesson, as long as he was in class. He did allow learners to use IWB to do some calculations as they interact with the lesson. Teacher Fortune indicated that she could show learners diagrams. It was also found that IWBs was not effectively used, as one of the teachers indicated that she does not use the IWB as prefers the textbook. Here Teacher Suzan indicated that she did not actually use the IWB as compared to the textbook.

In Question 3, teachers were requested to respond to the question: Does the IWB contain materials that assist you in doing lesson preparations and assessments? The theme, materials on IWB, was created. The findings revealed that most teachers agreed that IWBs has various teaching and learning materials. Teacher Duma indicated that the material that was on the IWB was only the textbook for learners. Teacher Noble said, yes, IWB do have material, but he does not know how to use it. Teacher Zelda said, yes, even the books are there, and the assessment is there in the books. Some of the teachers did not know that an IWB contains teaching and learning materials. Teacher Gordon said the IWB currently does not have what he needed. Teacher Chama indicated no, she used and created her own material. Some of the teachers indicated that the textbook was the material that was on the IWB. Teacher Shabane indicated that IWB contains a textbook, the same as the hardcopy that we have. Teacher Peters 
revealed that the material on the IWB was only the textbook for learners. Teacher Zulu said the IWB contains material in the textbooks, which were loaded for them to use.

Some of the teachers explained in detail the kind of material contained in IWBs, such as diagrams, videos experiments and charts, which makes the lesson easier. For example, Teacher Chabalala stated that he could show learners diagrams. Teacher Song indicated he interacts with learners using videos and other technologies on the IWB. It makes lessons much easier than the chalkboard. Teacher Sammy and Teacher Farmer indicated that they used IWB for projecting lessons, videos, and experiments. Teacher Jabu indicated that according to the IWB he could represent some charts by using the material on it. Other teachers revealed that they use IWBs as a teaching aid whereby they project the lesson. Teacher Zack mentioned that normally he used it as a teaching aid to show and project lessons. Teacher Wally indicated that he used the $I W B$ to project the lessons. The findings also revealed that teachers used IWBs as a projector. Teacher Xulu indicated that she could save her material from the laptop and prepare the lessons from home. Then she could use her laptop and project it on the IWB. The findings revealed that the teachers taught a variety of subjects using IWBs. Teacher Thomas indicated that he is teaching Life Orientation using the IWB. Teacher Maphalala taught Life Sciences with the aid of an IWB. Teacher Mofokeng taught Mathematical Literacy lessons. The findings also revealed that some of the teachers indicated there was no teaching and learning material. Teacher Nkosi said no, the IWB did not contain any material. Teacher Akani indicated the IWB currently did not have what she needed.

\section{Discussions}

The results revealed that $92.7 \%$ of the participants received formal training in the use of IWBs. However, the training received was inadequate. The training was characterized by hours, two days, and/or weeks of training. This was not satisfactory according to the participants, as most training sessions were carried out by education officials who lacked pedagogical knowledge. The importance of training by experts in the technology in question was also mentioned in previous studies, which state that teacher training should be conducted by professional bodies [6]. This pattern of training impacted negatively on teachers' use of IWBs in pedagogy, as more focus was on technology. These findings confirm previous studies indicating that poor training leads to no usage, or under-usage of ICT technology within a teaching and learning environment [31].

The most notable use of IWBs by teachers was that of a writing board, as they were observed writing notes on the IWB using their fingers. Some teachers prepared lessons and saved them onto the IWB. These findings imply that teachers did not fully utilize the interactive features offered by an IWB. How teachers used the IWB encouraged PowerPoint presentations, which naturally supports a teacher-centered approach. This finding is consistent with [3] results. Video-based lessons were found to be the most favoured by teachers. It may be argued that videos were found to be popular in the use of technology in teaching [32]. The findings in this study further highlighted that teachers were unable to add new information to their lesson using the IWB, leading to the compromise of the lesson.

The findings revealed that, in most cases, teachers complained about the lack of teaching and learning materials available through IWBs. Some teachers identified videos and chart materials contained in the IWB. However, it was found that some of the teachers could not use the material embedded in the IWB, while others opted to create their own material. This could be due to teachers' inability to utilize the IWB. The most accessed material was by means of uploaded textbooks. Accessing the textbook from the IWB did not improve the quality of the lesson, as it did not engage the interactive features of the IWB. The results showed that teachers complained about the lack of African language materials in the IWB. [21] furthermore mentioned the local language barrier in IWBs. It may be argued that IWBs have been imported from other countries, and as a result, it contains pre-programmed languages only. The lack of materials was found to be consistent with [3], as it posed challenges for meaningful integration processes. Generally, IWBs had materials for subjects such as Mathematics, Accounting, and Sciences, which could be influenced by these subjects' universal acceptance.

In this study, the challenges observed include technical issues, teaching material and lessons, lack of engagement, health, and lack of electricity. Concerning technical challenges with IWBs, it was found that teachers in this study were stuck. IWB freezes were slow to restart, and slow to access material due to a lack of internet access. Furthermore, teachers did not know how to switch audio, troubleshoot the IWBs having no signal and therefore not responding when switched on, and lacked knowledge on how to link learners' mobile devices to the IWB. It may be argued that teachers lost valuable teaching time while trying to fix the gadgets. [7] also reported IWB technical challenges. About teaching material and lessons, it was found that teachers struggled to use the interactive features on the IWB due to the lack of internet connectivity, as they reverted to PowerPoint presentations. Furthermore, the African language material posed a huge challenge, as only the textbook was uploaded. It was a paper behind the screen, with no interactive features. In terms of lack of engagement, it was found that learners were not involved in the learning process. A teacher-centered approach was more dominant, which 
surpassed the powerful benefit of IWBs. The findings revealed that IWBs posed multiple challenges to teachers relating to health hazards, as they experienced eye problems. In addition, the bright light displaying from IWBs was also reported to be a concern by [20]. In South Africa, electricity failure or load shedding poses serious challenges to the use of IWBs, as lessons could not be presented using the tool. Load shedding is the act or practice of temporarily reducing the supply of electricity to a specific area in an attempt to avoid the overloading of a targeted electricity grid [33]. This condition forced the teachers to revert to whiteboards. [7] also reported an electricity challenge.

The results in this study showed that teachers' confidence in solving problems when using IWBs, could moderately solve IWB problems, or were unable to solve problems. It was found that $65.0 \%$ of the teachers could moderately solve problems when using IWBs at $40 \%$. It may be argued that teachers' inability to solve technical issues, or lack of technical support, contributed to this. Furthermore, teachers opted to use IWBs as a paper behind the screen, and neglected the interactive features that improve student engagement, interactivity, and participation. Since an IWB is a technology that fosters learners' cooperation and active participation in the lesson, the IWB could facilitate cohesive and participative classroom learning as a whole [8]. It may be seen from the results that $75.6 \%$ of the teachers indicated their inability to solve problems when using an IWB at $90 \%$. This means that the problem-solving self-efficacy of teachers to utilize IWBs was extremely low. It should be noted that a low problem-solving self-efficacy may affect a teacher's confidence [34]. This was seen when some of the teachers struggled to use the IWB in class, thereby indicating that teachers were not properly equipped to use the IWB technology, hence lack problem-solving skills to troubleshoot. Teachers with a negative problem orientation regard a problem as a threat to their own survival. They believe that problems are difficult to solve. They lack confidence in themselves and become agitated easily when confronted with a problem [14]. This was also observed in this study when teachers opted to use the whiteboard.

This paper presented the challenges encountered by teachers, and their lack of solving problems when teaching with IWBs. It is essential to provide teachers with solutions to increase their level of confidence. Firstly, continuous IWB pedagogical professional development should be conducted. Educational experts should be consulted for any professional opportunities available to teachers, as not everyone can provide solutions. [35]. These authors emphasize pedagogy rather than technology. Teachers should be provided with technical support in order to improve their confidence in integrating interactive features on the learning activities to make it interesting for the learners and promote active learning.
The capacity to apply unique software tools for focusing attention, contributing to learning scaffolding, bringing forth pedagogical changes, and exhibit, explain, and solve problems, are some of the solutions to effectively use IWBs [8]. To help the teachers to increase their confidence in solving problems with IWBs, [7] it is suggested that teachers should make problem-solving the focus of the class by presenting a problem to the class, and thereafter assign it to the learners to solve. In this case, learners could better collaborate in the classroom with the IWB technology [7]. As it was stated, problem-solving styles include cognitive and behavioral processes that assist people to grasp challenges and discover solutions [14]. As problems are unavoidable and a source of stress and anxiety, it is believed that teachers need to acquire problem-solving skills leading to the more effective utilization of IWBs. The study conducted by [15], which aimed to alleviate anxiety among College Algebra learners, demonstrates problem-solving efficacy. It may be argued that teachers should attempt positive problem orientation, so that they would be more likely to observe a problem as a challenge, suggesting that problems do exist, and should be addressed accordingly. If teachers could adopt positive problem orientation, they could be successful in solving the challenges posed using IWBs.

\section{Conclusion}

It was found in this study that the dialogic or interactive teaching promoted by IWBs was not realized. It was reported that teachers either underutilized IWBs or did not make use IWBs at all. This posed challenges, as the DBoE invested heavily in the IWBs in high schools. It was stated that problem-solving self-efficacy could be a solution to this challenge. The type of IWB training offered to the teachers in this study also posed a challenge. It was mentioned that teachers were not fully equipped to utilize the IWB technology. The continuous professional development, with the focus on pedagogy, was seen as a solution. It has been reported that most teachers had low self-efficacy and are unable to solve IWB problems. The study encouraged teachers to embrace positive problem orientation, as they could be efficacious in IWB problem-solving.

\section{Recommendations}

It is critical that teachers are to be provided with technicians to support IWB technical challenges, allowing teachers to solely focus on pedagogy. It is recommended that teachers who would like to use IWB in their teaching practices consider the challenges and solutions provided in this study to avoid such. It is necessary to investigate the efficacy of the solutions presented in this study when 
using IWBs. A further study can be conducted with a sample of learners. Further research might be carried out in other Gauteng Districts to determine whether the findings of this study could be replicated.

\section{REFERENCES}

[1] Jensen, K., "The impact of interactive touchscreens on physics education in upper secondary school: A systematic literature review,” Dissertation, Linköpings Universitet, 2017, http://urn.kb.se/resolve?urn=urn:nbn:se:liu:diva-150344

[2] Mokoena, M. M, Simelane-Mnisi, S. Mji, A., Coetzer, L.M.J, "Exploring the effects of the use of interactive whiteboard on teachers' professional development in South African high schools,” In M.P. Sebola, T Molokwane. Proceedings of the 4th Annual Conference on Democracy, Elections and Administration in Africa. South Africa: Johannesburg 2019, pp. 183 - 199.

[3] Bardakci, S., Ünver, T. K., "Teachers and interactive whiteboards: A qualitative investigation in the margin of technophobia,” Australian Educational Computing, vol. 35, no. 1, 2020. https://orcid.org/0000-0001-5482-5962

[4] Noh, N. H., Yusoff, S., Hassanuddin, N. A., Sukri, N. B. M., “Adopting the 'explain EDU' application approach in teaching mathematics and statistics," e-Academia Journal of UiTM Cawangan Terengganu, vol. 1, no. 10, pp. 29-35, 2021. https://doi.org/10.24191/e-aj.v10i1.13356.

[5] Perinpasingam, P. T., Ling, C. H., Supramaniam, K., "Needs analysis of student use of technology focusing on interactive whiteboard during classroom presentations," Higher education challenges in South-East Asia, IGI Global, pp. 135-149, 2021. DOI: 10.4018/978-1-7998-4489-1ch00 7.

[6] Ifeakor, A. C., Akujieze, M. O., Erutujiro, G., "Effect of interactive whiteboard on students' academic achievement in mathematics in Onitsha North L. G. A of Anambra State, Nnadiebube,” Journal of Education in Africa, vol. 6, no. 1, pp. 40-51, 2020. https://www.acjol.org/index.php/,jea/artic le/view/551/555

[7] Mihai, M. A., "The use of interactive whiteboards in urban Gauteng classrooms,” Perspectives in Education, vol. 38, no. 2, pp. 321-336, 2020. http://dx.doi.org/10.18820/25195 93X/pie.v38. i2.21.

[8] Wujec-Kaczmarek, A., "The application of interactive whiteboard technology in general education and English Language Teaching (ELT): A literature overview,” DOI: 10.30438/ksj.2021.9.1.5.

[9] Bunch, J. C., Robinson, J. S., Edwards, M. C., "Measuring the relationship between Agriculture teachers' self-efficacy, outcome expectation, interest, and their use of interactive whiteboards," Journal of Agricultural Education, vol. 53, no. 1, pp. 67-80, 2012, DOI: 10.5032/jae.2012.01067.

[10] Bandura, A., "Self-efficacy: Toward a unifying theory of behavioural change,” Psychological Review, vol. 84, no. 2, pp. 191-215, 1977.

[11] Hillier, E., Beauchamp, G., Whyte, S., “A study of self-efficacy in the use of interactive whiteboards across educational settings: A European perspective from the ITILT project,” Educational Futures, vol. 5, no. 2, pp. 3-23, 2013, http://www.educationstudies.org.

[12] De Santis, J. D., "Exploring the effects of professional development for the interactive whiteboard on teachers' technology self-efficacy," Journal of Information Technology Education Research, vol. 12, pp. 343-362, 2013, http://www.jite.org/documents/Vol12/JITEv12ResearchP3 43362DeSantis0374.pdf.

[13] Turgut, E., Sökmen, A., “The effects of perceived organizational ethics on innovative work behavior: Self-efficacy's moderating and mediating role,” Turkish Journal of Business Ethics, 2018, DOI http://dx.doi.org/10.12711/tjbe.2018.11.1.0007.

[14] Erözkan, A., "Analysis of social problem solving and social self-efficacy in prospective teachers," Educational Sciences: Theory \& Practice, vol. 14, no. 2, pp. 447-455, 2014, DOI: 10.12738/estp.2014.2.2014

[15] Anoling, O. C. Jr., Dagdag, J. D., Pascual, J. F., Salviejo, R. P., "Factor structure of problem-solving efficacy among college algebra,” Journal of Research, Policy \& Practice of Teachers \& Teacher Education, vol. 8, no. 2, pp. 19-28, 2018. https://doi.org/10.37134/jrpptte.vol8.no2.32018

[16] Gregorcic, B., Etkina E., Planinsic, G., “A New way of using the interactive whiteboard in a high school physics classroom: A case study,” Research Science Education, vol. 48, pp. 465-489, 2018. DOI: 10.1007/s11165-016-9576-0.

[17] Olivares, D. D., Castillo, R. R., "ICT in the classroom: primary education student teachers' perceptions of the interactive whiteboard during the teaching practicum," Education and Information Technologies, vol. 23, no. 6, pp. 2309-2321, 2018. https://doi.org/10.1007/s10639-018-9716 $-4$

[18] Tatli, C., Kiliç, E., "Interactive whiteboards: Do teachers really use them interactively?” Interactive Learning Environments, vol. 24, no. 7, 2016. https://doi.org/10.1080/ 10494820.20151016536

[19] Aliyu, J., Osman, S., Daud, M. F., \& Kumar, J. A. (2021). "Mathematics teachers' pedagogy through technology: A systematic literature review," International Journal of Learning, Teaching and Educational Research, vol. 20, no. 1, pp. 323-341, 2021. DOI.org/10.26803/ijlter.20.1.18

[20] Van, L. H. H., Hiep, N. X., "Motivating freshmen in learning vocabulary with innovative interactive whiteboard activities, harmony in diversity," Proceedings of the Transcultural Society, Thailand, TESOL, pp. 172-196, 2020.

[21] Mokoena, M. M., “Exploring teachers' efficacy in the use of interactive whiteboards in Gauteng," Master's Degree in Education, Tshwane university of Technology, Pretoria, South Africa, 2019.

[22] Alkiş, Y., "The lived experiences of high school teachers with different subject matters pertaining to the use of interactive whiteboard (IWB): A phenomenological study," Doctor of Philosophy in Computer Education and 
Instructional Technology Department, Middle East Technical University, 2020. etd.lib.metu.edu.tr

[23] Baharudin, H. H., Masnan, A. H., Zain, A., "The advantages of interactive whiteboard technology in the development of children's learning," Turkish Journal of Computer and Mathematics Education, vol. 12, no. 3, pp. 842-845, 2021. https://doi.org/10.17762/turcomat.v12i3.792

[24] Aisyah, K., "The learning English website as the alternative media to enhance the economics students' competence in learning English,” Journal of English Literature, Linguistic and Education, vol. 2, no. 1, pp. 1-9, 2021.

[25] Gumpert, A. J., "The use of a computer-supported learning design to support oral language development among English language learners through the design process," University of California Los Angeles, 2020.

[26] Creswell, J. W., Plano Clark, V. L., "Designing and conducting mixed methods research," Thousand Oaks: Sage, 2007.

[27] Lapan, S. D., Quartaroli, M. T., "Research essentials. An introduction to designs practices," San Francisco: Jossey-Bass, 2009.

[28] Pajares, F., Hartley, J., Valiante, G., "Response format in writing self-efficacy assessment: Greater discrimination increases prediction," Measurement and Evaluation in Counseling and Development, vol. 33, no. 4, pp. 214-221, 2001. DOI: 10.1080/07481756.2001.12069012.
[29] Cronbach, L. J., "Coefficient alpha and the internal structure of tests,” Psychometrika,” vol. 16, pp. 297-334, 1951.

[30] Bless, C., Higson-Smith, C., Sithole, S. L., "Fundamentals of social research methods: an African perspective," Fifth edition, Juta \& Co, 2013.

[31] Bueno-Alastuey, M. C., Villarreal, I., "Pre-service teachers' perceptions and training contributions towards ICT use," Estudios Sobre Educación, 2021. DOI: 10.15581/004.41.002.

[32] Zheng, L., Bhagat, K. K., Zhen, Y., Zhang, X., “The effectiveness of the flipped classroom on students' learning achievement and learning motivation: A meta-analysis," Educational Technology \& Society, vol. 23, no. 1, pp. 1-15, 2020. https://www.jstor.org/stable/26915403

[33] Collins Dictionary, "Collins's dictionary of the English language,”@eng, London (UK), Collins, 2015.

[34] Bandura, A., "Guide for constructing self-efficacy scales," In F. Pajares., T. Urdan (Eds.), Self-efficacy beliefs of adolescents, Greenwich,” CT: Information Age Publishing, vol. 5, pp. 307-337, 2006.

[35] Simelane-Mnisi S., Mji A., "Preparing lecturers for remote teaching and flexible learning during COVID-19 pandemic," The 13 Annual International Conference on Education Research Innovation, Spain, Seville, virtual conference, pp. 9111-9120, 2020. 